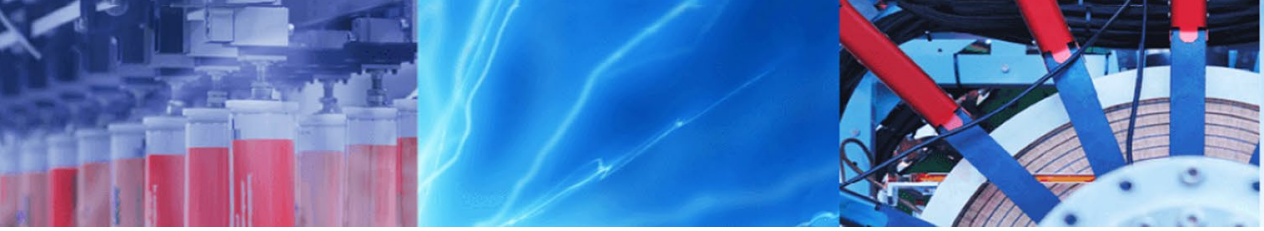

Research Article

\title{
Effects of high-temperature heating and cryogenic quenching on the physico-mechanical properties of limestone
}

\author{
Rohan Bisai $^{1} \cdot$ Sathish Kumar Palaniappan ${ }^{1} \cdot$ Samir Kumar Pal $^{1}$
}

Received: 9 November 2019 / Accepted: 3 January 2020 / Published online: 6 January 2020

(c) Springer Nature Switzerland AG 2020

\begin{abstract}
This paper is designed to investigate the influence of high-temperature heating and cryogenic quenching using liquid nitrogen (LIN) cooling on the physico-mechanical properties of limestone such as compressive strength, tensile strength, ultrasonic pulse velocity (UPV) and morphological characterization. The main aim is to provide a better understanding on influence of the temperature shock including high temperature pre-treatments and combined process with heating followed by LIN quenching on the physico-mechanical properties of rock. The samples were subjected to different thermal treatment using high-temperature of $100^{\circ} \mathrm{C}, 200^{\circ} \mathrm{C}, 400^{\circ} \mathrm{C}$ and $600^{\circ} \mathrm{C}$ for $4 \mathrm{~h}$. In addition, the combined process of heating at $600^{\circ} \mathrm{C}$ for $4 \mathrm{~h}$ and LIN quenching for $15 \mathrm{~min}, 30 \mathrm{~min}, 45 \mathrm{~min}$ and $60 \mathrm{~min}$ has also been explored. The obtained results indicate that pre-treatments in limestone depict decreasing trend in strength values. Limestone samples show $62 \%$ drop in uniaxial compressive strength (UCS) and $84 \%$ drop in Brazilian tensile strength (BTS) for $600{ }^{\circ} \mathrm{C}$ pre-treatment for $4 \mathrm{~h}$, whereas the decrease in $70 \%$ of UCS and $89 \%$ of BTS are also observed for the combined process with 60 min of LIN quenching. The influence of pre-treatment on UPV and microstructure of rock has been investigated in detail. Due to thermal stress, very low UPV has been obtained for the pre-treated samples compared to untreated. SEM analysis has been carried out to understand the fracture morphology for both untreated and treated rock samples.
\end{abstract}

Keywords High temperature · Liquid nitrogen · Physico-mechanical properties · Limestone

\section{Introduction}

Globally, researchers attempted many thermal pre-treatments of rocks to estimate the effect of those treatments on the technical properties of rocks. The influence of high temperature on the properties of rocks is very much important for practical engineering applications. Due to high temperature treatment, the mechanical properties such as strength, Young modulus and Poisson's ratio are severely affected. The study on deviation in rock properties due to thermal cracking is relevant to various engineering applications. To overcome those limitations, the influence of high temperature on the different rocks is a key topic for research. The changes in rock properties due to high temperature treatments have been noticed by various researchers [1-4]. It has been concluded that the effect of treatment depends on different properties of rock such as mineral composition, porosity, density etc. Darot and Reuschle had chosen granite as raw material and tested at a temperature of $510^{\circ} \mathrm{C}$ under the different ranges of confining pressure [5]. They have concluded that the permeability of rock enhanced with the increased effective pressure. Chaki et al. noticed the influence of thermal treatment of rock for the temperatures up to $600^{\circ} \mathrm{C}$ and got the good consistency between the results [6]. Liang et al. studied the effect of high temperature on the physico-mechanical parameters of rock, whereas the ultrasonic velocity of samples decreased and also the

Rohan Bisai, rohan.bisai1@gmail.com; Sathish Kumar Palaniappan, sathishiitkgp@gmail.com; Samir Kumar Pal, pal.samir09@gmail.com | ${ }^{1}$ Department of Mining Engineering, Indian Institute of Technology Kharagpur, Kharagpur, West Bengal 721302, India. 
compressive strength decreased with increasing temperature [7]. David et al. investigated the thermal crack generation of granite due to increment in temperature [8]. Wang et al. choose red sandstone to understand the effect of thermal treatment on the mechanical properties [9]. Rock sample was heated to $200^{\circ} \mathrm{C}$ and then immerged into water for the thermal shock and for this shock the mechanical properties of the sandstone decreased. Jason et al. investigated thermal cracking of rock and noticed the intergranular cracks occurred due to the temperature shock [10]. Hamand-Etienne et al. showed the transformation of mechanical behavior of rock due to high temperature up to $600^{\circ} \mathrm{C}[11]$. The tensile strength and elastic modulus decreased with increasing temperature. There are two important parameters i.e., porosity and seismic velocity for evaluation of the influence of pores and cracks inside the rocks due the thermal treatment [12]. Brotons et al. exhibited the influence of thermal shock on Calcarenite rock sample [13]. They have investigated that UCS of Calcarenite reduces up to $35 \%$ followed by air-cooled and $50 \%$ followed by water-cooled condition at the temperature difference of $105-600^{\circ} \mathrm{C}$. Young's modulus has been reduced over $75 \%$ and $78 \%$ respectively. It was established that UCS of Calcarenite is the most sensitive parameter to cooling condition. Chakrabarti et al. reported that at the temperature above $250-300^{\circ} \mathrm{C}$, there are some changes in color for sandstone [14]. Sandstone, changes its color from brown to reddish brown but the change may not be clearly seen until the stone has been heated to the temperature above $400{ }^{\circ} \mathrm{C}$. Wu et al. researched different types of sandstones and concluded that after $400{ }^{\circ} \mathrm{C}$, strength was decreased and a sharp drop between 400 and $600{ }^{\circ} \mathrm{C}$ temperature, when strength is just fewer than $60 \%$ of the initial value [15]. Koca et al. tested nine intact marble samples under various temperatures to determine the strength of rock [16]. They had collected rock samples from building elements and they have also tested five samples from it. It was reported that material's UCS exposed to $500{ }^{\circ} \mathrm{C}$ and then drop in temperature shows very similar UCS values with the material which was tested at $500{ }^{\circ} \mathrm{C}$. Variations in wave velocity and porosity of sandstone after high-temperature treatment have been investigated by Hu et al. When the temperature is higher than $400^{\circ} \mathrm{C}$, porosity quickly increases, and wave velocity sharply decreases [17]. Zhang et al. studied the thermal effect on physical and mechanical properties of rock at $25-500{ }^{\circ} \mathrm{C}$. The physico-mechanical properties of rocks such as compressive strength, tensile strength and wave velocity changed apparently due to the high temperature treatment. The tensile strength, compressive strength and wave velocity decreased due to the increasing number of micro fracture inside the rock [18]. Peng et al. concluded that the thermal damage has a great effect on physical and mechanical properties of the rock sample. With increasing temperature, the non-linearity in the initial deformation stage is gradually enhanced [19]. González-Gómez et al. tested four limestones and showed the effect of thermal degradation on the compression strength, ultimate compression strain, color and mass loss of rock sample [20]. High temperatures cause degradation of natural stones. Strength of the natural stones is adversely affected by the increase of temperature and started decreasing with $600^{\circ} \mathrm{C}$ and above [21]. Ding et al. have studied the effects of temperature $\left(200,400,600\right.$ and $\left.800{ }^{\circ} \mathrm{C}\right)$ and confining pressure $(20,30$ and $40 \mathrm{MPa})$ on the mechanical properties of sandstone. Decrease in peak effective loading stress was observed with enhanced temperature and varies accordingly with change in initial confining pressure [22].

According to the literature review, most of the researchers have given priority to the individual high temperature treatment or LIN treatment; but the effect of both combined treatments is more effective as the sudden temperature changing occurred during the quenching process. Bisai et al. conducted some experiment on treating granite and sandstone samples with LIN and concluded that granite sample shows more than $40 \%$ reduction in ultimate tensile strength and $28 \%$ in UCS, whereas sandstone samples depict drop in UCS of $33 \%[23,24]$. This present paper aims to provide a better understanding on influence of the temperature shock including high temperature pre-treatments and combined process with heating followed by LIN quenching on the physico-mechanical properties of rock. Limestone is considered as the raw material for this study to understand the physico-mechanical (UCS, BTS, UPV and SEM) behavior under different pre-treatment conditions.

\section{Materials and methods}

\subsection{Specimen and preparation}

In this study, limestone has been selected as appropriate rock samples for understanding the influence of pretreatments and combined process of pre-treatment and sudden quenching. The cores were saw cut into uniaxial compression and Brazilian test specimen. The samples were prepared according to ISRM standards with the correct length to diameter ratio. The cylindrical samples were polished before testing. The samples were air dried to maintain the constant mass. Also, the chemical composition of the limestone which is used in the present studies has been identified. Energy dispersive X-ray (EDX) analysis using ZEISS EDS detector is used to solve the above purpose. Figure 1 and Table 1 show the elemental composition and their corresponding weight percentage in limestone sample. The samples dimensions of UCS and 


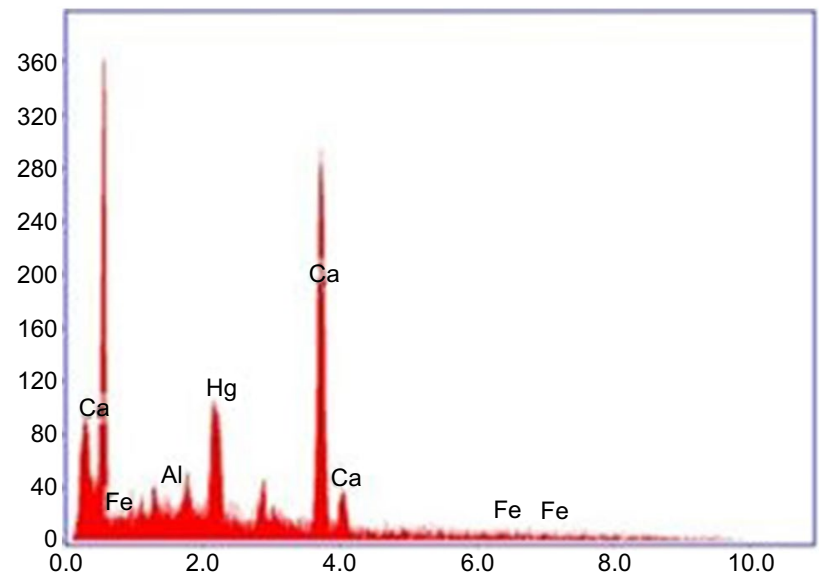

Fig. 1 EDX analysis of limestone

Table 1 Elemental details of limestone samples

\begin{tabular}{lcc}
\hline Element & Weight (\%) & Atomic (\%) \\
\hline Al K & 12.83 & 18.05 \\
Ca K & 85.26 & 80.75 \\
Fe K & 1.70 & 1.16 \\
Hg L & 0.21 & 0.04 \\
\hline
\end{tabular}

BTS tests are illustrated in Tables 2 and 3 with the suitable pre-treatments and their corresponding results. A total of 36 samples were prepared for the present study.
Two samples for each pre-treatment method have been tested and the average values were tabulated.

\subsection{Thermal treatment}

The different types of pre-treatments are as follows:

(i) Heat treatment using furnace The samples undergone furnace treatment at the temperature of $100{ }^{\circ} \mathrm{C}, 200{ }^{\circ} \mathrm{C}, 400{ }^{\circ} \mathrm{C}, 600{ }^{\circ} \mathrm{C}$ for $4 \mathrm{~h}$. After the treatment, the samples were allowed to cool in normal room temperature before testing. The samples under furnace treatment are shown in Fig. 2. However, before pre-treatment, initial properties of limestone were measured in order to establish a good comparison in normal room temperature $\left(25^{\circ} \mathrm{C}\right)$.

(ii) Heat treatment and sudden cryogenic quenching Initially, the samples were treated in furnace at $600^{\circ} \mathrm{C}$ temperature for $4 \mathrm{~h}$ and suddenly quenched in LIN for different time durations like $15 \mathrm{~min}, 30 \mathrm{~min}$, $45 \mathrm{~min}$ and $60 \mathrm{~min}$. The samples under cryogenic quenching are shown in Fig. 3.

\subsection{Instruments and test methods}

\subsubsection{Determination of compressive strength}

In this paper, the mechanical test of rocks involves determination of UCS. An INSTRON make, SATEC series KN
Table 2 Sample details for uniaxial compression strength (UCS) tests of limestone

\begin{tabular}{lllc}
\hline Sample no. & $\begin{array}{l}\text { Dimensions (D in } \\
\mathrm{mm} / \mathrm{L} \text { in } \mathrm{mm} \text { ) }\end{array}$ & Pre-treatment & UCS (MPa) \\
\hline LC 1 & $55.1 / 118.30$ & None & 158.67 \\
LCF 1 & $55.1 / 121.60$ & Heating at $100^{\circ} \mathrm{C}$ for $4 \mathrm{~h}$ & 150.21 \\
LCF 2 & $55.0 / 110.91$ & Heating at $200^{\circ} \mathrm{C}$ for $4 \mathrm{~h}$ & 141.33 \\
LCF 3 & $55.1 / 116.16$ & Heating at $400^{\circ} \mathrm{C}$ for $4 \mathrm{~h}$ & 129.39 \\
LCF 4 & $55.3 / 111.63$ & Heating at $600^{\circ} \mathrm{C}$ for $4 \mathrm{~h}$ & 50.44 \\
LCFL 1 & $55.0 / 112.81$ & Heating at $600^{\circ} \mathrm{C}$ for $4 \mathrm{~h}+$ LIN quenching for 15 min & 81.63 \\
LCFL 2 & $55.1 / 112.82$ & Heating at $600^{\circ} \mathrm{C}$ for $4 \mathrm{~h}+$ LIN quenching for 30 min & 79.16 \\
LCFL 3 & $55.1 / 112.50$ & Heating at $600^{\circ} \mathrm{C}$ for $4 \mathrm{~h}+$ LIN quenching for 45 min & 66.88 \\
LCFL 4 & $55.1 / 114.96$ & Heating at $600^{\circ} \mathrm{C}$ for $4 \mathrm{~h}+$ LIN quenching for 60 min & 47.18 \\
LC 2 & $55.1 / 108.37$ & None & 152.40 \\
LCF 5 & $55.1 / 111.46$ & Heating at $100{ }^{\circ} \mathrm{C}$ for $4 \mathrm{~h}$ & 153.16 \\
LCF 6 & $55.0 / 112.58$ & Heating at $200^{\circ} \mathrm{C}$ for $4 \mathrm{~h}$ & 129.96 \\
LCF 7 & $55.2 / 114.89$ & Heating at $400^{\circ} \mathrm{C}$ for $4 \mathrm{~h}$ & 102.22 \\
LCF 8 & $55.0 / 110.71$ & Heating at $600^{\circ} \mathrm{C}$ for $4 \mathrm{~h}$ & 66.31 \\
LCFL 5 & $55.0 / 115.32$ & Heating at $600^{\circ} \mathrm{C}$ for $4 \mathrm{~h}+$ LIN quenching for $15 \mathrm{~min}$ & 60.88 \\
LCFL 6 & $55.2 / 116.25$ & Heating at $600^{\circ} \mathrm{C}$ for $4 \mathrm{~h}+$ LIN quenching for 30 min & 58.63 \\
LCFL 7 & $55.1 / 111.11$ & Heating at $600^{\circ} \mathrm{C}$ for $4 \mathrm{~h}+$ LIN quenching for 45 min & 55.28 \\
LCFL 8 & $55.0 / 110.93$ & Heating at $600^{\circ} \mathrm{C}$ for $4 \mathrm{~h}+$ LIN quenching for 60 min & 46.39 \\
\hline
\end{tabular}



Brazilian tensile strength (BTS) tests of limestone
Table 3 Sample details for

\begin{tabular}{|c|c|c|c|}
\hline Sample no. & $\begin{array}{l}\text { Dimensions ( } D \text { in } \\
\mathrm{mm} / \mathrm{L} \text { in } \mathrm{mm} \text { ) }\end{array}$ & Pre-treatment & BTS (MPa) \\
\hline LT 1 & $55.1 / 27.00$ & None & 12.43 \\
\hline LTF 1 & $55.1 / 27.20$ & Heating at $100^{\circ} \mathrm{C}$ for $4 \mathrm{~h}$ & 12.66 \\
\hline LTF 2 & $55.1 / 27.30$ & Heating at $200^{\circ} \mathrm{C}$ for $4 \mathrm{~h}$ & 9.15 \\
\hline LTF 3 & $55.0 / 28.10$ & Heating at $400^{\circ} \mathrm{C}$ for $4 \mathrm{~h}$ & 7.50 \\
\hline LTF 4 & $55.0 / 27.30$ & Heating at $600^{\circ} \mathrm{C}$ for $4 \mathrm{~h}$ & 1.20 \\
\hline LTFL 1 & $55.3 / 28.33$ & Heating at $600^{\circ} \mathrm{C}$ for $4 \mathrm{~h}+\mathrm{LIN}$ quenching for $15 \mathrm{~min}$ & 1.69 \\
\hline LTFL 2 & $55.0 / 27.12$ & Heating at $600^{\circ} \mathrm{C}$ for $4 \mathrm{~h}+\mathrm{LIN}$ quenching for $30 \mathrm{~min}$ & 1.54 \\
\hline LTFL 3 & $55.0 / 27.39$ & Heating at $600^{\circ} \mathrm{C}$ for $4 \mathrm{~h}+\mathrm{LIN}$ quenching for $45 \mathrm{~min}$ & 2.01 \\
\hline LTFL 4 & $55.0 / 27.00$ & Heating at $600^{\circ} \mathrm{C}$ for $4 \mathrm{~h}+\mathrm{LIN}$ quenching for $60 \mathrm{~min}$ & 1.12 \\
\hline LT 2 & $55.1 / 27.10$ & None & 11.08 \\
\hline LTF 5 & $55.1 / 27.20$ & Heating at $100^{\circ} \mathrm{C}$ for $4 \mathrm{~h}$ & 11.90 \\
\hline LTF 6 & $55.2 / 27.00$ & Heating at $200^{\circ} \mathrm{C}$ for $4 \mathrm{~h}$ & 10.11 \\
\hline LTF 7 & $55.1 / 27.33$ & Heating at $400^{\circ} \mathrm{C}$ for $4 \mathrm{~h}$ & 6.57 \\
\hline LTF 8 & $55.1 / 27.17$ & Heating at $600^{\circ} \mathrm{C}$ for $4 \mathrm{~h}$ & 2.58 \\
\hline LTFL 5 & $55.3 / 27.00$ & Heating at $600^{\circ} \mathrm{C}$ for $4 \mathrm{~h}+$ LIN quenching for $15 \mathrm{~min}$ & 2.01 \\
\hline LTFL 6 & $55.0 / 27.00$ & Heating at $600^{\circ} \mathrm{C}$ for $4 \mathrm{~h}+$ LIN quenching for $30 \mathrm{~min}$ & 1.82 \\
\hline LTFL 7 & $55.1 / 27.32$ & Heating at $600^{\circ} \mathrm{C}$ for $4 \mathrm{~h}+\mathrm{LIN}$ quenching for $45 \mathrm{~min}$ & 1.29 \\
\hline LTFL 8 & $55.0 / 27.11$ & Heating at $600^{\circ} \mathrm{C}$ for $4 \mathrm{~h}+\mathrm{LIN}$ quenching for $60 \mathrm{~min}$ & 1.23 \\
\hline
\end{tabular}

\subsubsection{Determination of Brazilian tensile strength}

Brazilian test is proposed for the measurement of indirect tensile strength of a rock specimen. BTS of the sample is calculated by dividing the maximum load carried by the sample during the test, by the contact area of the sample. The BTS is calculated as described below:

$\mathrm{BTS}=\frac{2 \mathrm{P}_{\max }^{\prime}}{\pi \mathrm{DL}}$

where $\mathrm{P}_{\text {max }}^{\prime}=$ load at failure during the test, $\mathrm{D}=$ diameter of the sample, $L=$ axial length of the sample.

\subsubsection{Ultrasonic pulse velocity (UPV) test}

Fig. 2 Samples under furnace pre-treatment at $600^{\circ} \mathrm{C}$ temperature

model, universal testing machine (UTM) was used in this study, as shown in Fig. 4. As explained earlier, all the experiments were performed at normal room temperature. UCS is the compressive stress at which the sample fails was calculated by using the following formula.

Cylindrical limestone core samples with diameter around $55-55.3 \mathrm{~mm}$, length of $110.2-121.6 \mathrm{~mm}$ and velocity measuring equipment (as shown in Fig. 5) were used in this study based on the ISRM (2007) recommendations. The present UPV unit has two transducers including one transmitter and one receiver with a frequency of $150 \mathrm{kHz}$.

$U C S=\frac{P_{\max }}{\pi D^{2} / 4}$

where $P_{\max }=$ load at failure, $\mathrm{D}=$ diameter of the sample. 


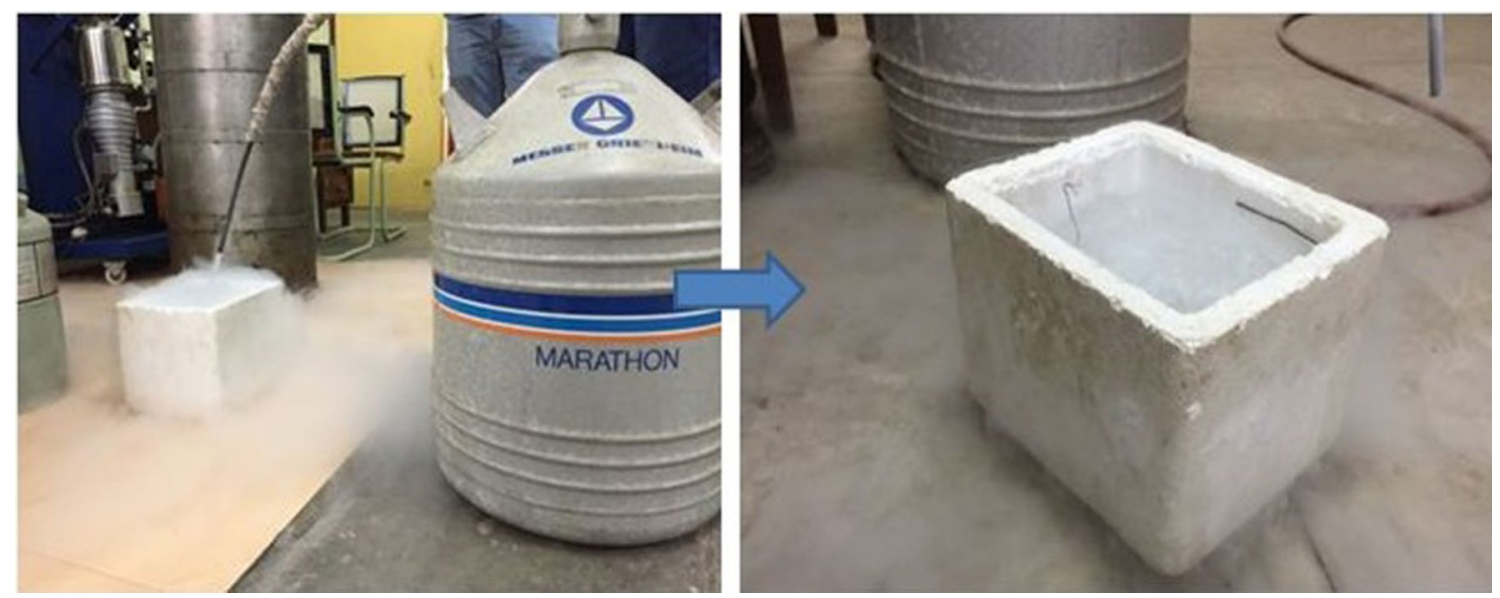

Fig. 3 Samples under cryogenic treatment using LIN

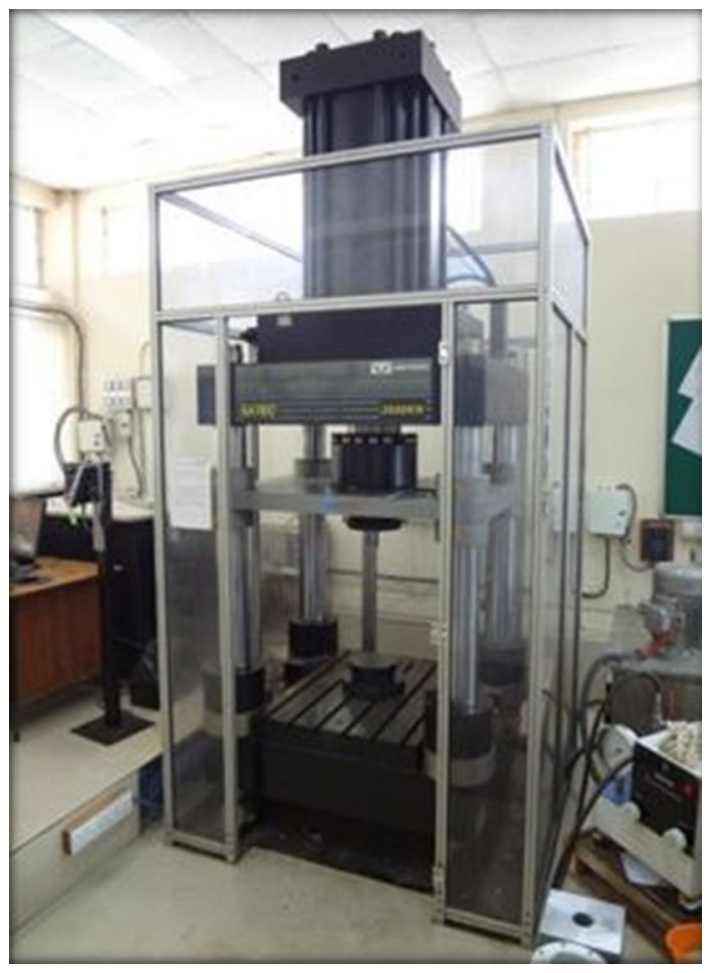

Fig. 4 UTM machine

\section{Results and discussions}

\subsection{Mechanical properties}

The UCS and BTS results of limestone with high temperature treatment and cryogenic quenching were presented in Figs. 6, 7, 8 and 9. Decreasing trend in both the strengths was observed for all the cases. The amount of decrease, however, varies with the samples as well as with the duration of pre-treatment. Figures 6 and 7 illustrate the UCS and BTS of limestone samples under varying pre-treatment conditions. Significant drop in UCS was observed in case of heat treatment at $600^{\circ} \mathrm{C}$. The treated samples (heating at $600{ }^{\circ} \mathrm{C}$ for $4 \mathrm{~h}$ ) show reduction in UCS by $62 \%$ (Fig. 6 ) and BTS by $84 \%$ (Fig. 7) compared to untreated samples. The rise in strength after $100^{\circ} \mathrm{C}$ temperature is probably due to the effect of structural reorientation of the molecules without developing any significant thermal crack. The structural reorientation can be found in metals during cryogenic treatment of cutting tools [25] which helps in increasing the strength of the tools. However, in rocks, corroboration with more investigation is needed. Figures 8 and 9 demonstrate the UCS and BTS of limestone samples under varying pre-treatment conditions followed by LIN quenching. Significant drop in UCS was observed in case of heat treatment at $600{ }^{\circ} \mathrm{C}$ and sudden LIN quenching for $60 \mathrm{~min}$. The treated samples (combined process of heating at $600{ }^{\circ} \mathrm{C}$ for $4 \mathrm{~h}$ and LIN quenching for $60 \mathrm{~min}$ ) depict reduction in UCS by $70 \%$ (Fig. 8) and BTS by $89 \%$ (Fig. 9) compared to untreated samples.

\subsection{Effect of pre-treatment on the physical properties}

This paper explains the influence of high temperature treatment i.e., $600^{\circ} \mathrm{C}$ for $4 \mathrm{~h}$ and sudden LIN quenching on the physical properties of limestone. A significant decrease has been monitored in the UPV test of the pre-treated sample. Before pre-treatment, the properties of limestone were measured in order to provide a good comparison in normal room temperature $\left(25^{\circ} \mathrm{C}\right)$. The sample lengths and the corresponding UPV test results are tabulated in Tables 4 and 5. Two samples were tested in each case and the average results were noted down. Figures 10 and 11 
UPV tester

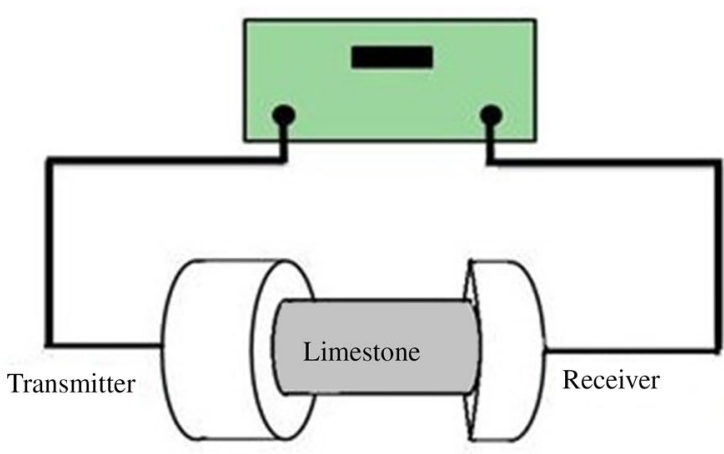

Fig. 5 Ultrasonic pulse velocity (UPV) testing apparatus

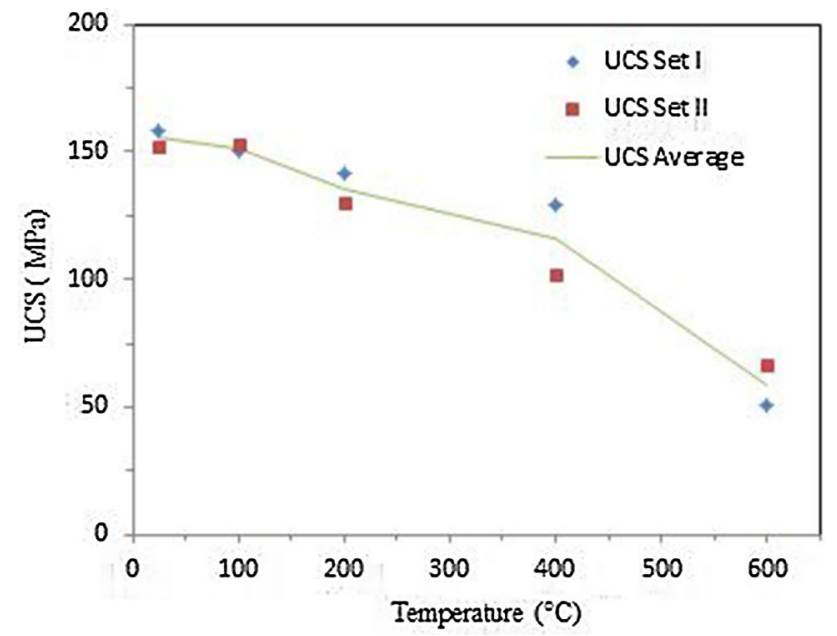

Fig. 6 UCS of limestone with varying duration of individual pretreatment

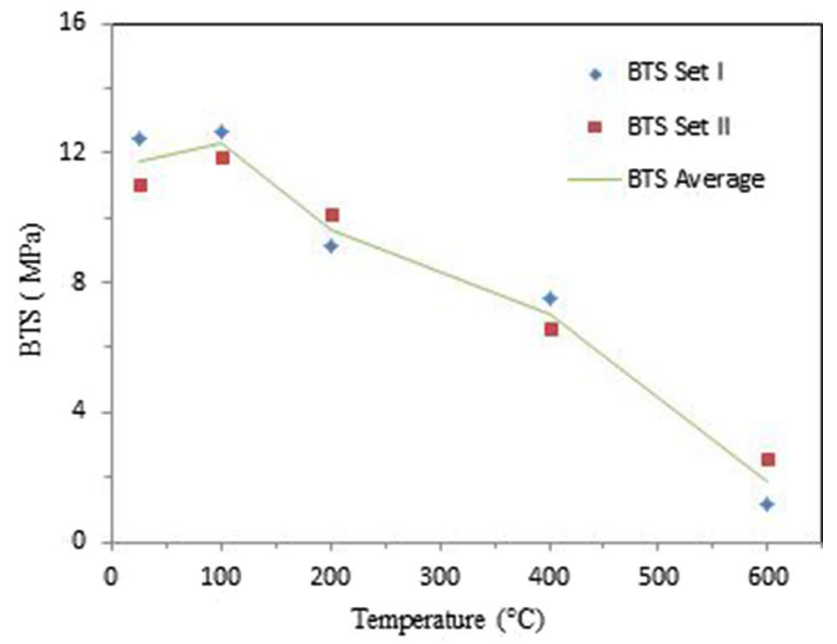

Fig. 7 BTS of limestone with varying duration of individual pretreatment
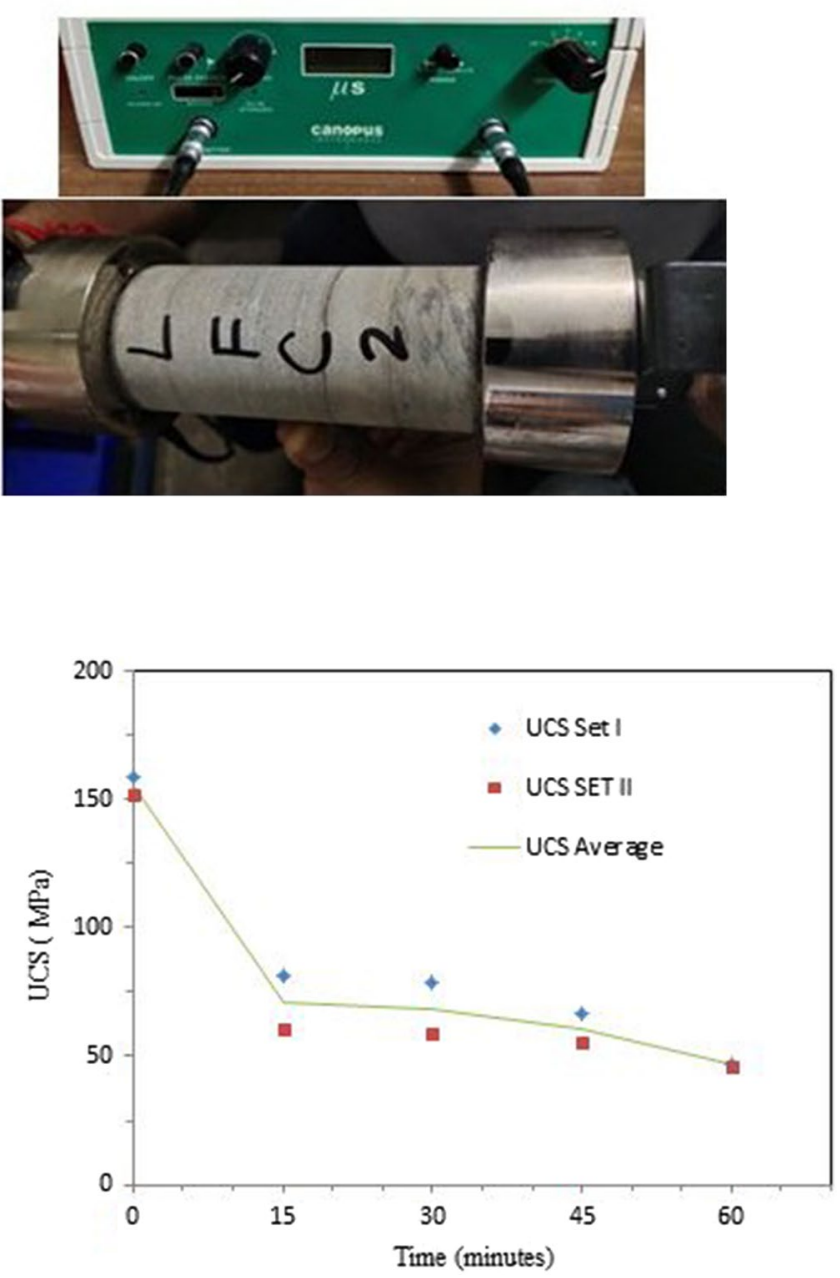

Fig. 8 UCS of limestone with combined process of pre-treatment at $600{ }^{\circ} \mathrm{C}$ for $4 \mathrm{~h}$ followed by varying duration of LIN quenching

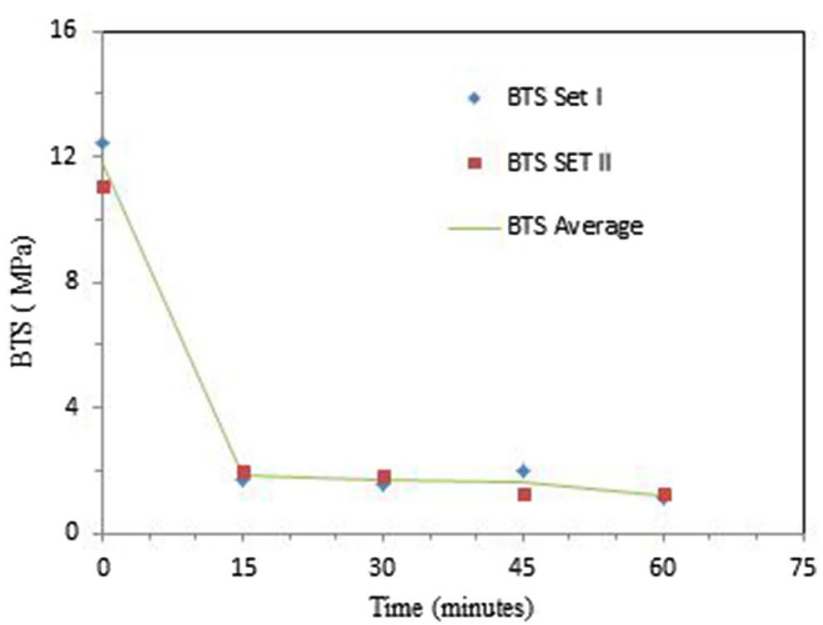

Fig. 9 BTS of limestone with combined process of pre-treatment at $600^{\circ} \mathrm{C}$ for $4 \mathrm{~h}$ followed by varying duration of LIN quenching 
Table 4 Comparison of ultrasonic pulse velocity (UPV) test results between high temperature pre-treated limestone and untreated limestone samples

\begin{tabular}{lllr}
\hline Sample no. & Distance $(\mathrm{m})$ & Time $(\mathrm{s})$ & UPV $(\mathrm{m} / \mathrm{s})$ \\
\hline LC 1 & 0.1183 & 0.0000191 & 6193.717 \\
LCF 1 & 0.1216 & 0.0000216 & 5629.630 \\
LCF 2 & 0.1109 & 0.0000249 & 4453.815 \\
LCF 3 & 0.1161 & 0.0000355 & 3270.423 \\
LCF 4 & 0.1116 & 0.0001577 & 707.673 \\
LC 2 & 0.1083 & 0.0000210 & 5157.143 \\
LCF 5 & 0.1114 & 0.0000214 & 5205.607 \\
LCF 6 & 0.1125 & 0.0000361 & 3116.343 \\
LCF 7 & 0.1148 & 0.0000425 & 2701.176 \\
LCF 8 & 0.1107 & 0.0001609 & 688.005 \\
\hline
\end{tabular}

Table 5 Comparison of ultrasonic pulse velocity (UPV) test results between combined process of pre-treated limestone at $600{ }^{\circ} \mathrm{C}$ for $4 \mathrm{~h}$ followed by LIN quenching and untreated limestone samples

\begin{tabular}{lllr}
\hline Sample no. & Distance $(\mathrm{m})$ & Time $(\mathrm{s})$ & UPV $(\mathrm{m} / \mathrm{s})$ \\
\hline LC 1 & 0.1183 & 0.0000191 & 6193.717 \\
LCFL 1 & 0.1128 & 0.0001569 & 718.929 \\
LCFL 2 & 0.1128 & 0.0002299 & 490.648 \\
LCFL 3 & 0.1125 & 0.0002714 & 414.517 \\
LCFL 4 & 0.1149 & 0.0003117 & 368.623 \\
LC 2 & 0.1083 & 0.0000210 & 5157.143 \\
LCFL 5 & 0.1153 & 0.0001712 & 673.481 \\
LCFL 6 & 0.1162 & 0.0002971 & 391.114 \\
LCFL 7 & 0.1111 & 0.0002990 & 371.571 \\
LCFL 8 & 0.1109 & 0.0003290 & 337.082 \\
\hline
\end{tabular}

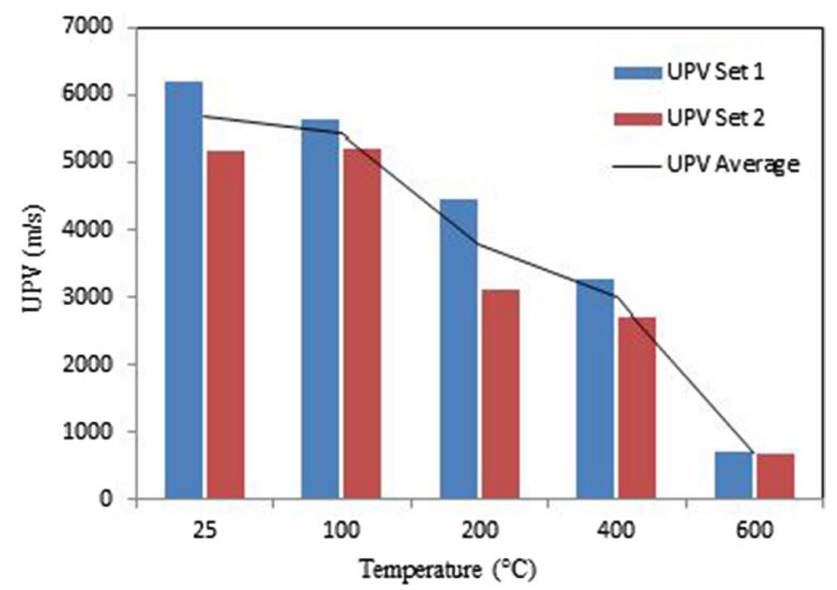

Fig. 10 UPV of limestone with varying duration of individual pretreatment

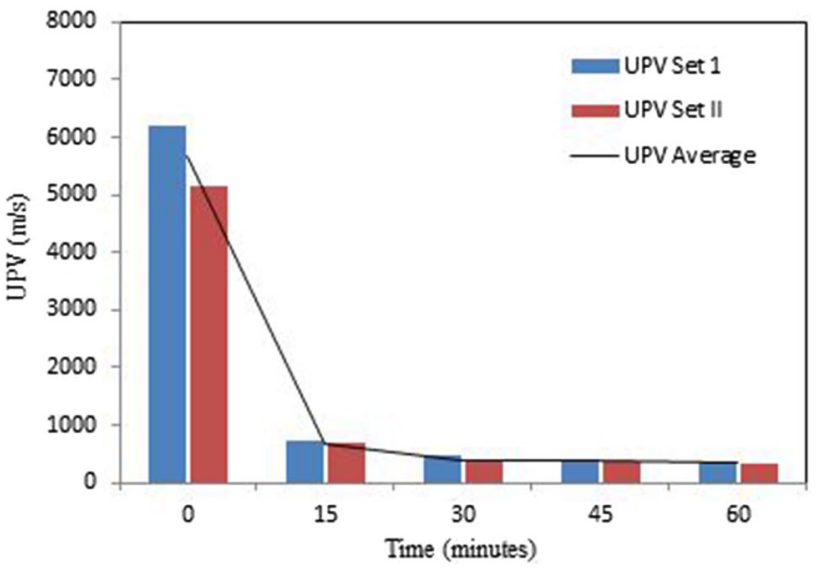

Fig. 11 UPV of limestone with combined process of pre-treatment at $600{ }^{\circ} \mathrm{C}$ for $4 \mathrm{~h}$ followed by varying duration of LIN quenching

explain the UPV results of two samples at two different working conditions. As shown in tables, untreated sample has UPV values of $6193.7 \mathrm{~m} / \mathrm{s}$ and $5157.1 \mathrm{~m} / \mathrm{s}$, which was classified as very high velocity [26]. However, the samples after pre-treatment at $600{ }^{\circ} \mathrm{C}$ for $4 \mathrm{~h}$ has UPV values of $707.7 \mathrm{~m} / \mathrm{s}$ and $688 \mathrm{~m} / \mathrm{s}$, which was considered as very low velocity. Similarly, LIN quenching treatment is more effective than the single treatment of high temperature. So, the samples undergone pre-treatment at $600{ }^{\circ} \mathrm{C}$ for $4 \mathrm{~h}$ followed by sudden LIN quenching of $60 \mathrm{~min}$ displays UPV values as $368.62 \mathrm{~m} / \mathrm{s}$ and $337.18 \mathrm{~m} / \mathrm{s}$, which was still considered to be a very low velocity. These results indicated that granular cementation is damaged and cracks have generated on the rocks may be the reason behind this findings. In addition, several micro-fissures can also be generated in its inter-grain due to the thermal stress during high temperature treatment and LIN quenching. The significant decrease in UPV values with gradual increase in temperature and duration of LIN quenching has been studied and depicted in Figs. 10 and 11. As like all the experiments, two samples were tested in each case and the average results were noted down for further interpretation.

\subsection{Effect of pre-treatment on the morphological characterizations}

For understanding the mineral grain structure of rock through microscope, SEM was used in this study. It is one of the significant techniques to understand the microstructure of rocks. The mineral grain distribution and the micro-fissures in the rocks have been seen with proper magnifications. Accordingly, SEM was utilized to quantify the surface micro-topographies of rock slices before and after pre-treatment. The outcomes are subjectively 


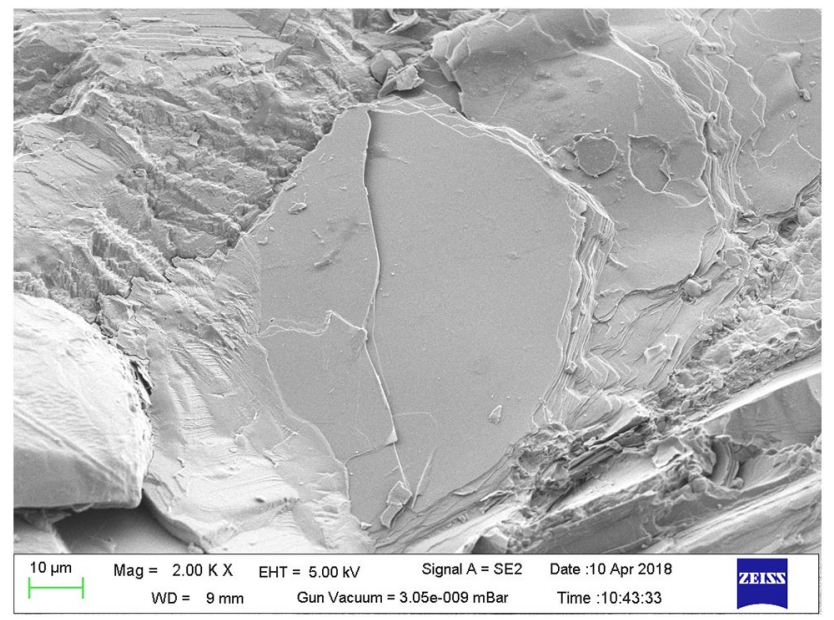

Fig. 12 SEM image of untreated limestone sample

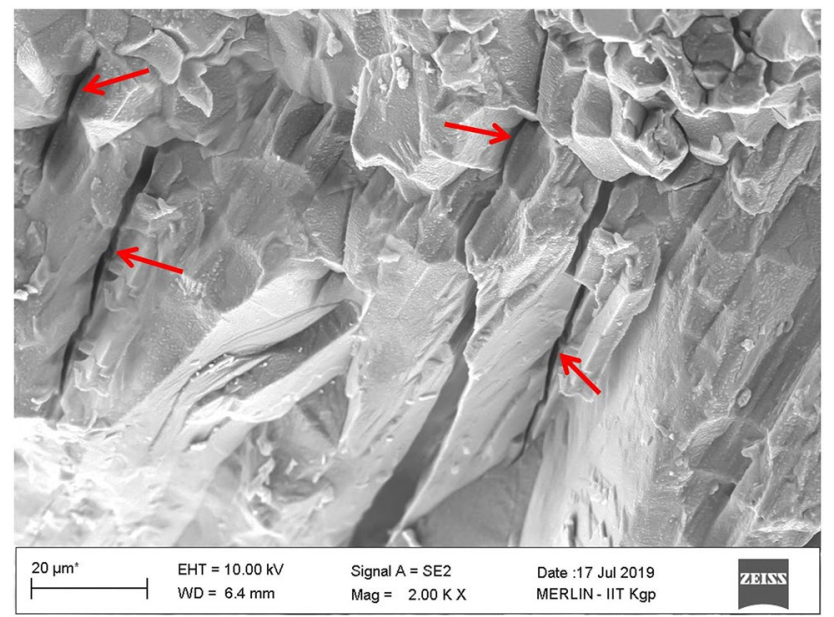

Fig. 13 SEM image of limestone sample with individual pre-treatment at $600{ }^{\circ} \mathrm{C}$ for $4 \mathrm{~h}$

investigated to derive the effect of heat treatment on the pore structure of rocks. SEM analyses of the pre-treated and untreated samples were done by utilizing ZEISS scanning electron microscope. Figures 12,13 and 14 depict the SEM images of limestone samples before pre-treatment, after pre-treatment at $600{ }^{\circ} \mathrm{C}$ for $4 \mathrm{~h}$ and thirdly, pretreatment at $600^{\circ} \mathrm{C}$ for $4 \mathrm{~h}$ followed by LIN quenching for 60 min respectively. The analysis has been performed at a magnification of $2 \mathrm{~K}$ times to understand mineral grain distribution of limestone. The arrangements of mineral grains in the limestone are very compact and it has good inter-grain cementation. However, the untreated granite sample (Fig. 12) does not show any fracture. Figures 13 and 14 depict that the inter-grain cementation is damaged and the cracks have appeared. Several micro-fissures have been found in its inter-grain, which shows the thermal

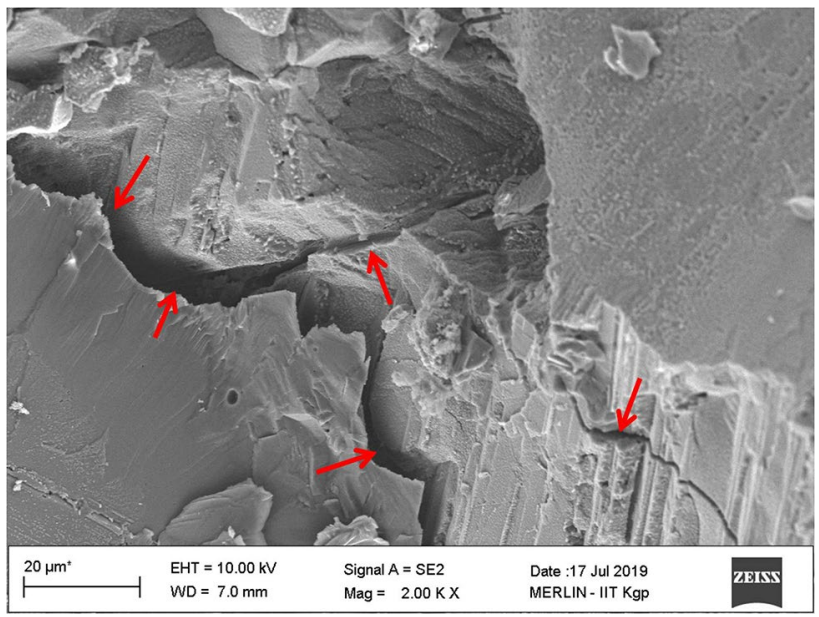

Fig. 14 SEM image of limestone sample with combined process of pre-treatment at $600{ }^{\circ} \mathrm{C}$ for $4 \mathrm{~h}$ followed by LIN quenching for $60 \mathrm{~min}$

stress created during LIN cooling, whereas high temperature treatment breaks the granular cementation and new cracks are generated.

\section{Conclusions}

The effect of rock pre-treatment including high temperature treatment and combined process of pre-treatment followed by LIN quenching were carried out for studying the physical and mechanical properties of limestone samples. Following salient points were observed from the experimental results.

- For limestone, $62 \%$ reduction in UCS was observed in $600^{\circ} \mathrm{C}$ high temperature pre-treatment for $4 \mathrm{~h}$ and $70 \%$ reduction was observed in combined process (heating at $600^{\circ} \mathrm{C}$ for $4 \mathrm{~h}$ followed by LIN quenching for $60 \mathrm{~min}$ ). Slight increases in strength properties are observed at $200{ }^{\circ} \mathrm{C}$. This increment in compressive strength possibly ascribed to the beginning of phase changes of the minerals which thus gave a temporary plastic reaction when externally loaded, prompting slight increment in strength at $200^{\circ} \mathrm{C}$.

- In terms of BTS of limestone, $84 \%$ reduction in UCS was observed in $600^{\circ} \mathrm{C}$ high temperature pre-treatment for $4 \mathrm{~h}$ and $89 \%$ reduction was observed in combined process (heating at $600^{\circ} \mathrm{C}$ for $4 \mathrm{~h}$ followed by LIN quenching for $60 \mathrm{~min}$ ). The combined process is more effective than individual pre-treatment process.

- The UPV results showed the same decreasing trend with the increasing temperature, whereas the velocity decreased to $697.85 \mathrm{~m} / \mathrm{s}$ in the case of $600{ }^{\circ} \mathrm{C}$ pre- 
treatment for $4 \mathrm{~h}$ and $352.9 \mathrm{~m} / \mathrm{s}$ in the combined process, which was considered as very low velocity. The UPV results mainly influenced due to the thermal stress induced due to sudden temperature changes and LIN quenching. The obtained UPV results are in line and support the UCS and BTS results of limestone in all the conditions.

After the phase change, as a result of thermal expansion of the different minerals, more micro-cracks have been developed in the rock which mainly affected the physico-mechanical behavior of the same. Advantage of pre-treatment on rocks is highly dependent on the mineral composition of those particular samples. To extend this area of research, the more detailed investigations on pretreatment methods along with other issues such as cost, complexity and feasibility etc. are considered to be very much essential.

\section{Compliance with ethical standards}

Conflict of interest On behalf of all authors, the corresponding author states that there is no conflict of interest.

\section{References}

1. Rao QH, Wang Z, Xie HF, Xie Q (2007) Experimental study of mechanical properties of sandstone at high temperature. J Cent South Univ Technol 14(1):478-483. https://doi. org/10.1007/s11771-007-0311-x

2. Zhang L, Mao X, Lu A (2009) Experimental study on the mechanical properties of rocks at high temperature. Sci China Ser E Technol Sci 52(3):641-646. https://doi.org/10.1007/ s11431-009-0063-y

3. Chen YL, Ni J, Shao W, Azzam R (2012) An experimental study on the influence of temperature on the mechanical properties of granite under a uni-axial compression and fatigue loading. Int J Rock Mech Min Sci 56(15):62-66. https://doi. org/10.1016/j.ijrmms.2012.07.026

4. Ranjith PG, Viete DR, Chen BJ, Perera MSA (2012) Transformation plasticity and the effect of temperature on the mechanical behaviour of Hawkesbury sandstone at atmospheric pressure. Eng Geol 151(151):120-127. https://doi.org/10.1016/j. enggeo.2012.09.007

5. Darot M, Reuschle T (2000) Acoustic wave velocity and permeability evolution during pressure cycles on a thermally cracked granite. Int J Rock Mech Min Sci 37(10):19-26. https ://doi.org/10.1016/S1365-1609(00)00034-4

6. Chaki S, Takarli M, Agbodjan WP (2008) Influence of thermal damage on physical properties of a granite rock: porosity, permeability and ultrasonic wave evolutions. Constr Build Mater 22(14):56-61. https://doi.org/10.1016/j.conbuildma t.2007.04.002
7. Liang WG, Xu SG, Zhao YS (2006) Experimental study of temperature effects on physical and mechanical characteristics of salt rock. Rock Mech Rock Eng 39(4):69-82. https://doi. org/10.1007/s00603-005-0067-2

8. David C, Menendez B, Darot M (1999) Influence of stressinduced and thermal cracking on physical properties and microstructure of La Peyratte granite. Int J Rock Mech Min Sci 36(4):33-48. https://doi.org/10.1016/S0148-9062(99)00010-8

9. Wang T, Tian S, Li G, Sheng M (2018) Selective adsorption of supercritical carbon dioxide and methane binary mixture in shale kerogen nanopores. J Nat Gas Sci Eng 50:181-188. https ://doi.org/10.1016/j.jngse.2017.12.002

10. Jason DP, Carlson SR (1993) Ultrasonic imaging and acoustic emission monitoring of thermally induced microcracks in Lac du Bonnet Granite. J Geophys Res 98(B12):22231-22243. https ://doi.org/10.1029/93JB01816

11. Homand Etienne F, Houpert R (1989) Thermally induced micro cracking in granites: characterization and analysis. J Rock Mech Min Sci Geomech Abstr 26(2):125-134. https:// doi.org/10.1016/0148-9062(89)90001-6

12. Jaeger JC, Cook NG, Zimmerman R (2007) Fundamentals of rock mechanics. Wiley, Hoboken. https://doi.org/10.1017/ CBO9780511735349

13. Brotons V, Tomas R, Ivorra S, Alarcon JC (2013) Temperature influence on the physical and mechanical properties of porous rock: San Julian's calcarenite. Eng Geol 167:117-127. https://doi.org/10.1016/j.enggeo.2013.10.012

14. Chakrabarti B, Yates T, Lewry A (1996) Effect of fire damage on natural stonework in buildings. Constr Build Mater 10:539544. https://doi.org/10.1016/0950-0618(95)00076-3

15. Wu G, Wang Y, Swift G, Chen J (2013) Laboratory investigation of the effects of temperature on the mechanical properties of sandstone. Geotech Geol Eng 31(2):809-816. https://doi. org/10.1007/s10706-013-9614-X

16. Koca MY, Ozden G, Yavuz AB, Kincal C, Onargan T, Kucuk K (2006) Changes in the engineering properties of marble in fire-exposed columns. Int J Rock Mech Min Sci 43:520-530. https://doi.org/10.1016/j.jirmms.2005.09.007

17. Hu J, Pan X, Zhang W (2019) Thermal effect on wave velocity of sandstone after high-temperature treatment: a review. Arab J Geosci 12:689. https://doi.org/10.1007/s12517-019-4906-y

18. Zhang W, Sun Q, Hao S, Geng J, Lv C (2016) Experimental study on the variation of physical and mechanical properties of rock after high temperature treatment. Appl Therm Eng 98:12971304. https://doi.org/10.1016/j.applthermaleng.2016.01.010

19. Peng J, Rong G, Cai M, Yao MD, Zhou CB (2016) Physical and mechanical behaviors of a thermal-damaged coarse marble under uniaxial compression. Eng Geol 200:88-93. https://doi. org/10.1016/j.enggeo.2015.12.011

20. González-Gómez WS, Quintana P, May-Pat A, Avilés F, MayCrespo J, Alvarado-Gil JJ (2015) Thermal effects on the physical properties of limestones from the Yucatan Peninsula. Int J Rock Mech Min Sci 75:182-189. https://doi.org/10.1016/j. ijrmms.2014.12.010

21. Ozguven A, Ozcelik Y (2014) Effects of high temperature on physico-mechanical properties of Turkish natural building stones. Eng Geol 183:127-136. https://doi.org/10.1016/j. enggeo.2014.10.006

22. Ding QL, Ju F, Mao XB, Ma D, Yu BY, Song SB (2016) Experimental investigation of the mechanical behavior in unloading conditions of sandstone after high-temperature treatment. Rock Mech Rock Eng 49(7):2641-2653. https://doi.org/10.1007/ s00603-016-0944-x 
23. Bisai R, Goel S, Hatwal A, Pal SK, Majumder AK, Nandi TK (2018) Effect of cryogenic pre-treatment on breakage characteristics of rocks. J Min Sci 54(2):202-211. https://doi.org/10.1134/ S1062739118023557

24. Bisai R, Palaniappan SK, Pal SK (2020) Influence of individual and combined pre-treatment on the strength properties of granite and sandstone. Arab J Geosci 13(1):7. https://doi. org/10.1007/s12517-019-5009-5

25. Smolnikov EA, Kossovich GA (1980) Cold treatment of cutting tools. Met Sci Heat Treat 22(10):704-705. https://doi. org/10.1007/BF00700559
26. Anon $\mathrm{OH}$ (1979) Classification of rocks and soils for engineering geological mapping. Part 1: rock and soil materials. Bull Int Asso Eng Geol 19:355-371. https://doi.org/10.1007/BF02600503

Publisher's Note Springer Nature remains neutral with regard to jurisdictional claims in published maps and institutional affiliations. 